\title{
Rural Women's Political Participation and its Impact on Society (A case study of District- Gwalior (Madhya Pradesh)
}

\author{
APARNA SINGH* \\ India \\ *Corresponding Author: APARNA SINGH, India
}

\section{INTRODUCTION}

Rural women play a catalytic role towards achievement of transformational economic, social and environmental changes required for sustainable development of society. The active participation of women on equal terms with men, at all levels of decision making and political involvement is essential to the achievement of equality, rural development, peace and democracy and the inclusion of their perspective and experiences into the decision making process.

The leadership and participation of rural women in shaping laws, strategies, policies and programes on all issues that affects their lives. It is possible through political participation of rural women at local and national level. Political empowerment helps rural women to claim their rights to land, leadership, opportunities and choices to participate in shaping laws, regulations, policies and programes.

Rural women's political participation and empowerment is not only essential for strengthening a nations democracy, their struggle against marginalization, trivialization and oppression but also key to their socio-economic development. Rural women's do not have the knowledge or awareness of their legal and political rights, so they do not participate in elections and political events of their communities. Rural women are under represented in institutions, governance and leadership, and have less decision making power.

Enactment of the seventy third constitutional amendment (1993) mandated the setting of three-tier Panchayati Raj system in rural area's with the objective of strong capable and energetic panchayats as a local self government unit is a revolutionary step in India. The power was mandated to be given to the rural people via the Gram Panchayats, Janpad Panchayats at Tehsil or Block level and Jila Panchayat at District levels, which would have regularly elected representatives. These representative play a decisive role in planning development and delivering services according to the local needs and conditions. One another revolutionary step was the reservation of one third seats for women which was later increased to fifty percent from 2009-10 by Madhya Pradesh Government.

Madhya Pradesh was the first state in the country, which conducted the Panchayat Elections with the implementation of three-tier Panchayat Raj system in May-June 1994. Fifth Panchayat Election conducted successfully in 2014-15 in the state. There are 360487 Panch (Ward member), 22604 Surpanch or gram pradhan, 6774 Janpad Panchayat members and 847 Jila Panchayat members elected through electoral process for five years. The sixth Panchayat election have postponed due to some political and pandemic (Covid-19) reasons. It is proposed to possibly conduct in mid 2021.

District Gwalior is situated in the Northern part of Madhya Pradesh. As per census (2011) data the total population of Gwalior District is 2032036 with $46.3 \%$ percent of female population. Gwalior district is historically associated with its cultural, Industrial and political background. At present Gwalior have 566 in habitant village with 298 Gram Panchayats.

In the Rural area of the district women play an important role in the rural economy as farmers, wage earners and entrepreneurs. They also take responsibility for the well-being of the members of their families, including food provision, care of children and elderly, care of livestock's, and also contribute an important share in the agriculture force work. They suffer from acute poverty, overdependence on agriculture and less economic productivity. Most of them are involved in low income jobs of unorganised sectors, agriculture or other allied activities. 
Rural Women's Political Participation and its Impact on Society (A case study of District- Gwalior (Madhya Pradesh)

Studies shows a positive correlations between increasing the labour force participation of women and a rise in G.D.P. It is possible that the participation of women in electoral process, leadership quality and decision making power will contribute to accelerate the development growth of the district through its involvement in different sector.

\section{OBJECTIVE}

(i) To determine the political participation of Rural Women in Panchayat elections at different levels.

(ii) To suggest possible solutions for political involvement, participation and empowerment of rural women to increase their contribution for the Soci-Economic development of the district.

\section{RESEARCH METHODOLOGY}

Proposed study mainly as descriptive in nature. This research paper is based on secondary data and informations collected from Panchayat elections reports of Madhya Pradesh State Election Commission, Bhopal. This paper primarily focused on rural women's political participation and empowerment and its impact on society.

As per the Madhya Pradesh Election Commissions - report of Fifth Panchayat Election (2014-15), there are 4301 Panch (Ward member), 256 Surpanch (Pradhan), 100 Janpad Panchayat members and 13 Jila Panchayat members elected from District Gwalior. There are 2247 Panch (Ward member), 130 Surpanch (Pradhan), 52 Janpad Panchayat members and 7 Jila Panchayat members elected from the female category.

Table. Rural Women's representation in Vth Panchayat Election District-Gwalior (Madhya Pradesh) (2014-15)

\begin{tabular}{|l|l|l|l|l|}
\hline \multirow{2}{*}{ S.No. } & \multirow{2}{*}{ Representative post } & \multicolumn{2}{l|}{ Women's Representatives } \\
\cline { 3 - 5 } & & Total Seats & Female Representative & Percentage \\
\hline 1. & Panch (Ward member) & 4301 & 2247 & 52.24 \\
\hline 2. & Surpanch (Pradhan) Janpad & 100 & 130 & 50.78 \\
\hline 3. & $\begin{array}{l}\text { Member } \begin{array}{l}\text { Panchayat } \\
\text { Pember Jila }\end{array} \\
\text { Panchayat }\end{array}$ & 13 & 52 & 52.00 \\
\hline & Total & $\mathbf{4 6 7 0}$ & $\mathbf{2 4 3 6}$ & 53.84 \\
\hline
\end{tabular}

Source: Madhya Pradesh Election Commission Panchayat Elections Report (2014-2015)

Through political empowerment of rural women she can think and analyse the present status of women and identify the social norms and constraints, which are big hurdles in their progress enabling themselves to participate and make appropriate changes in formation of women friendly laws, regulations, policies, programmes and decision making process. They introduce effective measures to use their potential for the Socio-economic development and contribute to increase G.D.P.

In the leadership of women representations as Surpanch member, Janpad Panchayat and member Jila Panchayat plays at active role in village development through different committee i.e. planning committee, development and finance committee with the co-ordination of government officials. They will also contribute in construction of village connected roads, internal roads, drinking water facilities, Toilets, Schools, Dispensaries, play grounds and Anganwadi centers. They also focused on water resource management and environment related work.

\section{FINDINGS}

(i) Women representatives mostly act as mouth-pieces of their male family member at Gram Panchayat level.

(ii) Lack of education, lack of political knowledge, gender and societal norm or social constraints, less participation in decision making process in domestic and other field are very big hurdle in the way of political participation and empowerment of Rural Women.

(iii) Enormous potential of Rural women contribute to socio-economic development and raise G.D.P. if the barriers to equality are addressed.

There have been so many examples where due to reservation policy for Panchayat certain women got elected in to the setup. But they acted merely as the mouth-piece of their male family members, so we 
see political participation of many women representative as a proxy candidate. They do not be deliver services to the community as per their choice, potential and grass root reality. They face many challenges and obstacles i.e. lack of education, low skills, low productivity, poor working conditions, limited social protection, undervalued and unorganised work, societal norms and attitudes. And less participation in decision making at different level.

Changing of political culture by both individuals and collective actions, for example educating about political structure, and how political power is exercised, improving public access to information and increasing respect by policy makers for opinions, voice and right to influence decision making.

Following measures can be used to increase political empowerment of women in such areas for rural women to increase the political participation and involvement in the political system and process.

\section{AWARENESS, EduCATION ANd Training}

Most of the rural women are unable to participate in politics due to lack of adequate political consciousness, knowledge, awareness, education and training. Most of them don't know how politics work, how do institutions govern the people. It is very necessary to aware them about their legal and political rights, electoral and political system, through educating them and promote participate and involvement in training programmes with the help of N.G.O's, Women's political education forum, self help groups and women democracy networks. National and local political party should arrange short-term training and awareness programmes related with women's political activation and campaigning for advocacy.

\section{Social Constraints To Women Participation}

The set of obstructions presented by the entrenched social and traditional structure, that create certain patterns of dispowerment and privilege like caste, gender, religion, sexuality, disability and many more several long hold social, cultural and traditional norms bar the women from participating in the electoral process both as contesting candidate and voters. These discriminatory laws, practices and structure discourage women to participate in political events and become leaders. Removal and reducing these discriminations can be the way for more participation and involvement in political events and other societal activities.

\section{COMPETENCY DEVELOPMENTS}

Skills and knowledge are the motivating factors of the economic growth and development of rural women concentrated in low skilled, low productivity, and low unpaid jobs with long working hours.

Rural women can be motivated to develop the competency to increase women's political participation and access to political institutions related with electoral process and political events through holding seminars, training progammes, skill development programmes, established formal and informal women caucuses and political parties supports.

Support policy analysis, promote human right education continue skill building and supports are another important tools of capacity building of Rural Woman to develop leadership, communication, managerial and finance related skills.

\section{Promote Gender - Equality}

Our religious practices are reflective of our male dominated political system and society. The politics is supposed to be a male dominated area and women are not supposed to participate in political events due to socio-cultural norms and traditional structure. We find gender - discrimination in education, employment, less pay compare to man, common civil rights and sexual harassment.

We can reduce gender - inequality through equal parenting between boys and girl child, increasing public consciousness, increase enforcement of existing laws, women entrepreneurship, mentorship programmes and political leadership. At present in the District there should be a fundamental demand for a policy for women farmers, which includes cultivators, agricultural labourers, pastoralists, livestocks rearers and forest workers. After this, their equal rights entitlement over land and access to input credits, markets and extension services must be insured. 


\section{SAFTY ISSUES}

Women most of the time do not feel safe to work outside, because of the safety issues and the news they hear, regarding the alarming number of rapes, sexual harassment cases. In General women also fear for their children or their own safety if they report cases of any times of harassment. Police councelling and legal services may be more difficult for women to access in rural areas. Women safety involves strategies, practices and polices which aim to reduce gender based violence, including fear of crime. Women safety involves safe space, freedom from poverty, financial security and autonomy and self worth.

Many groups organized different kind of events in order to address issues regarding to women safety such as workshops, seminars, educational progarmmes, conferences and forums, including marches, rallies and protests.

\section{CONCLUSION}

From the past few decades and especially in the last few years Indian women have taken a great stride in all fields of activities including policies. Yet a lot remains to be achieved.

Political participation and empowerment of Rural Women provide ample space for the building confidence, develop leadership qualities and aware their legal and political rights. Women leadership is also imperative for their communities particularly other women and adolescent girls. Efforts related with female literacy and quality education, better health care, recognition of their status and political empowerment needs to continue for ensuring better access for socio-economic development of the district. There is enormous potential of rural women to contribute to raise G.D.P. if barriers to equality are addressed.

\section{REFERENCE}

[1] Lori Beaman \& (2006) Rohini Pande : Women politicians, Gender Bias, and policy making in Rural India

[2] B. Vissandjee (2006) Shelly abdool Alisha Apley: Women's political participation in Rural India: SAGE publication, www. u.k.sageup.com/home.nav

[3] Dharuba Hazarika (2011): Women empowerment in India : A Brief discussion, published in International Journal of education planning and administration vol.1 NO.3 (2011) Page-199-2002

[4] Tiwari, S. (2012): Political consciousness among rural women Boloji.com 28.01.2012.

[5] Dharmendra Kumar Dubey (2013): Political consciousness among Rural Women in Indian Himalya: A study of kumaon hills. Published in Research on humanities and social sciences vol. 3 No.1 (2013)

[6] S. Mol P. Bhattacharya (2014): Empowerment of Rural Women through political participation in Pashchim Medinipur District, West Bengal. Published in Journal of Business management and Social Sciences research Vol. 3 No. 11-2014

[7] Panchayat Election Report (2014-15): State Election Commission, Madhya Pradesh Bhopal

Citation: Sampson M. Nathanailidis. "The Crimean Bridge and Its Effect in Vladimir Putin's Image as a Strong Leader" International Journal of Political Science (IJPS), vol 7, no.2, 2021, pp. 1-4. doi: https://doi.org/10.20431/2454-9452.0702001.

Copyright: () 2021 Authors. This is an open-access article distributed under the terms of the Creative Commons Attribution License, which permits unrestricted use, distribution, and reproduction in any medium, provided the original author and source are credited. 